ЕКОНОМІКО-

ЕКОЛОГІЧНІ

ПЕРСПЕКТИВИ

ВИРОЩУВАННЯ

ЕНЕРГЕТИЧНОЇ

ВЕРБИ

ЯЛТУШКІВСЬКОЮ

ДОСЛІДНО-

СЕЛЕКЦІЙНОЮ

СТАНЦІЮ ІБК І ЦБ НААН УКРАЇНИ
ГОНЧАРУК I.В., доктор економічних наук, професор кафедри економіки та підприємницької діяльності, проректор з науково-педагогічної, наукової та інноваційної діяльності

ЯРЕМЧУК Н.В., кандидат економічних наук, стариий викладач кафедри адміністративного менеджммену та альтернативних джерел енергї; Вінницький національний аграрний університет

(м. Вінниця)

У статті проаналізовано особливості енерговикористання в Україні, за результатами чого встановлено, що серед основних споживачів паливно-енергетичних ресурсів, найбільша частка належить аграрному сектору, який одночасно характеризується значним потенціалом біомаси придатної для виробництва біопалив.

Визначено, щзо найбільш перспективним джерелом для отримання теплової енергї є тверді біопалива, виробництво яких в Україні супроводжується дефрічитом якісної сировини. Аналіз проблеми дозволив генерувати ї рішення у вигляді культивування енергетичних плантацій рослин короткої ротації, зокрема енергетичної швидкорослої верби, на землях, виведених із сільськогосподарських сівозмін.

Встановлено, що, у перспективі реалізації описаного рішення, пріоритетними завданнями для наукових установ аграрного профілю є селекиія продуктивних сортів $i$ гібридів енергетичних рослин короткої ротащії, придатних для переробки у тверді біопалива, та розроблення технологій їх вирощування і переробки. Серед таких організаџій об'єктом дослідження було обрано Ялтушківську дослідно-селекиійну станщію Інституту біоенергетичних культур і иукрових буряків НААН України, яка займається селекиійною роботою та елітним насінництвом сільськогосподарських та біоенергетичних культур, зокрема й енергетичної верби.

У межах наукової діяльності Ялтушківської дослідно-селекиійної станції було проведено та проаналізовано досліди з технології вирощування енергетичної верби для виробництва твердих біопалив із різних аспектів виробничого ичклу, включно з внесенням поживних речовин, альтернативними практиками обробітку трунту, використанням покривних культур, схемою посадки рослин, особливостями росту біомаси, а також системою збирання та логістики.

Розкрито перспективи практичного використання енергетичної верби на основі проведених економічних розрахунків ефективності плантації площею 10 га. 3 а методологічну основу було обрано програму EcoWillow 2.0 - найповніший інструмент фінансового аналізу посівів насаджень енергетичної верби.

Визначено, що особливої уваги потребує реформування забезпечення тепловою енергією сільського населення через створення енергетичних кооперативів із використання 
та вирощування енергетичної верби на основі міжсекторної науково-виробничої інтеграчії на місцевому рівні, залучивщи, водночас, у ролі наукового партнера ННВК «Всеукраїнський науково-навчальний консориіум» для забезпечення координації комунікацій між наукою, громадськістю, владою та бізнесом.

Ключові слова: енергетична верба, біомаса, біоенергетика, економічний аналіз, тверді біопалива, енергоефективність, енергетичний кооператив.

Табл.: 5. Рис.: 1. Літ.: 17.

\title{
ECONOMIC AND ECOLOGICAL PERSPECTIVES OF ENERGY WILLOW CULTIVATION BY THE YALTUSHKIVSKA EXPERIMENTAL BREEDING STATION OF THE INSTITUTE OF BIOENERGY CROPS AND SUGAR BEETS OF THE NATIONAL ACADEMY OF AGRARIAN SCIENCES OF UKRAINE
}

\author{
HONCHARUK Inna, \\ Doctor of Economic Sciences, \\ Professor of the Department of Economics and Entrepreneurship, \\ Vice-Rector for Scientific and Pedagogical, Scientific and Innovative \\ Activities \\ YAREMCHUK Natalia, \\ Candidate of Economic Sciences, Senior Lecture \\ of the Department of Administrative Management \\ and Alternative Energy Sources, \\ Vinnytsia National Agrarian University \\ (Vinnytsia)
}

The article analyzes the peculiarities of energy consumption in Ukraine, and it is established that among the main consumers of fuel and energy resources, the largest share belongs to the agricultural sector, which is also characterized by the significant potential of biomass suitable for biofuel production.

It was determined that the most promising source of thermal energy should be solid biofuel, the production of which in Ukraine is accompanied by a shortage of quality raw materials. Analysis of the problem allowed generating its solution in the form of cultivation of energy plantations of plants of short rotation, in particular energy fast-growing willow on the lands, withdrawn from the agricultural rotation.

It is established that in the perspective of realization of the described solution, the priority tasks for scientific institutions of agrarian profile are selection of productive varieties and hybrids of short-rotation energy plants suitable for processing into rigid biofuels and development of technologies of their cultivation and processing. Among such organizations, the object of research was selected Yaltushkovo experimental breeding station of the Institute of bioenergy crops and sugar beet NAAS of Ukraine, that is engaged in breeding and elite seed production of agricultural and bioenergy crops, including energy willow.

In scientific activities of Yaltushkivska experimental breeding station were carried out and analyzed experiments on the technology of growing energy willow for the production of solid biofuel from various aspects of the production cycle, including the introduction of nutrients, alternative treatment practices, the use of cover crops, planting patterns, biomass growth features, as well as collection systems and logistics.

Prospects for the practical use of energy willow based on economic calculations made for 
the efficiency of a 10-hectare plantation were disclosed. EcoWillow 2.0 program was chosen as the methodological basis - the most complete tool for financial analysis of willow plantations.

It was determined that special attention should be paid to reforming the provision of heat energy to the rural population through the creation of energy cooperatives on the use and cultivation of energy willow on the basis of intersectoral scientific and production integration at the local level, involving as a scientific partner of the existing USEC "All-Ukrainian scientificeducational consortium» to ensure coordination of communication between science, public, government and business.

Key words: energy willow, biomass, bioenergy, economic analysis, solid biofuels, energy efficiency, energy cooperative.

Tabl.: 5. Fig.: 1. Ref.: 17.

\title{
ЭКОНОМИКО-ЭКОЛОГИЧЕСКИЕ ПЕРСПЕКТИВЫ ВЫРАЩИВАНИЯ ЭНЕРГЕТИЧЕСКОЙ ИВЫ ЯЛТУШКОВСКОЙ ОПЫТНО- СЕЛЕКЦИОННОЙ СТАНЦИЕЙ ИБК И СС НААН УКРАИНЫ
}

\author{
ГОНЧАРУК И.В., \\ доктор экономических наук, \\ профессор кафедры экономики и предпринимательской деятельности, \\ проректор по научно-педагогической, научной и инновационной \\ деятельности \\ ЯРЕМЧУК Н.В., \\ кандидат экономических наук, старший преподаватель \\ кафедры административного менеджмента \\ и альтернативных источников энергии, \\ Винницкий национальный аграрный университет
} (2. Винница)

В статье проанализированы особенности энергопотребления в Украине, по результатам чего установлено, что, среди основных потребителей топливноэнергетических ресурсов, наибольшая доля принадлежит аграрному сектору, который одновременно характеризуется значительным потенциалом биомассы, пригодной для производства биотоплив.

Определено, что наиболее перспективным источником для получения тепловой энергии следует считать твердые биотоплива, производство которых в Украине сопровождается дефиџитом качественного сырья. Анализ проблемы позволил генерировать ее решение в виде культивирования энергетических плантаџий растений короткой ротации, в частности энергетической быстрорастущей ивы, на землях, выведенных из сельскохозяйственного севооборота.

Установлено, что в перспективе реализации описанного решения приоритетными задачами для научных учреждений аграрного профиля является селекция производительных сортов и гибридов энергетических растений короткой ротаџии, пригодных для переработки в твёрдые биотоплива, и разработка технологий их выращивания и переработки. Среди таких организаций объектом исследования была выбрана Ялтушковская опьтноселекционная станция Института биоэнергетических культур и сахарной свеклы НААН Украины, занимающеяся селекиионной работой и элитным семеноводством сельскохозяйственных и биоэнергетических культур, в том числе и энергетической ивы.

В рамках научной деятельности Ялтушковской опытно-селекциионной станции были 
проведены и проанализированы опыты по технологии выращчивания энергетической ивы для производства твердых биотоплив из различных аспектов производственного цикла, включая внесение питательных веществ, альтернативные практики обработки, использования покровных культур, схема посадки растений, особенности роста биомассы, а также системы сбора и логистика.

Раскрыты перспективы практического использования энергетической ивы на основе проведенных экономических расчетов эффективности плантаџии площадью 10 га. $3 a$ методологическую основу была выбрана программа EcoWillow 2.0 - наиболее полный инструмент финансового анализа посевов ивовых насаждений.

Определено, что особого внимания требует реформирование обеспечения тепловой энергией сельского населения путем создания энергетических кооперативов по использованию и вырашиванию энергетической ивы на основе межсекторной научнопроизводственной интеграции на местном уровне, задействовав при этом в качестве научного партнера действующий УНПК «Всеукраинский научно-учебный консорчиум» для обеспечения координации коммуникаций между наукой, общественностью, властью $и$ бизнессом.

Ключевые слова: энергетическая верба, биомасса, биоэнергетика, экономический анализ, твердые биотоплива, энергоэффективность, энергетический кооператив.

Табл.: 5. Рис.: 1. Лит.: 17.

Постановка проблеми. Зростання енергетичних потреб України, енергетична залежність, вичерпний характер корисних копалин і надмірне забруднення навколишнього середовища спрямовують все більше уваги науковців до перспектив використання нетрадиційних відновлювальних джерел енергії. «Енергетична стратегія України на період до 2035 року», зокрема пункт освоєння нетрадиційних і відновлюваних джерел енергії, потрібно розглядати як важливий чинник підвищення рівня енергетичної безпеки та зниження антропогенного впливу енергетики на довкілля. Використання потенціалу альтернативної енергетики в Україні має не тільки внутрішнє, а й значне міжнародне значення, як суттєвий чинник протидії глобальним змінам клімату.

Одним із вагомих напрямів розвитку альтернативної енергетики $\epsilon$ виробництво і використання біопалив. Сучасний етап виробництва твердих біопалив в Україні супроводжується відсутністю стабільного постачання якісної сировини для переробних підприємств протягом року. Цю проблему можливо вирішити завдяки створенню енергетичних плантацій високопродуктивних культур із високою врожайністю біомаси та підвищеним вмістом целюлози. На особливу увагу заслуговує напрям вирощування нових видів високопродуктивних багаторічних рослин із коротким періодом ротації. У зв'язку з невибагливістю до умов вирощування, значною продуктивністю та високою якістю отриманої біомаси, найбільш перспективними багаторічними рослинами для виробництва твердих біопалив в Україні вчені визначають міскантус (Miscanthus), світчграс (Panicum virgatum) та енергетичну вербу (Salix).

Особливої уваги у науковому дослідженні заслуговує енергетична верба, оскільки ця рослина має багато важливих характеристик, зокрема високі врожаї, здатність до повторного розростання після переливу та збирання кожні 3-4 роки, легкість розмноження зі сплячих стеблевих живців, легкість 
розведення, широку генетичну базу для селекції, що робить іiі ідеальною сировиною для виробництва біопалив. В Україні значна частина сільських населених пунктів не газифікована та знаходиться на пічному опаленні, що свідчить про необхідність змінювати традиційні підходи до теплозабезпечення. Реалізація таких завдань стає можливою завдяки інтеграції науки та виробництва у єдину симбіотичну систему. Суттєві напрацювання в цьому напрямку здійснили науковці Ялтушківської дослідно-селекційної станції Інституту біоенергетичних культур і цукрових буряків НААН України, яка вирощує вдосконалені сорти енергетичної верби як для ринків біомаси, так i для агролісомеліорації.

Аналіз останніх досліджень і публікацій. Проблемам енергетичного забезпечення України та іiі сільських територій присвятив свої праці вчений Калетнік Г.М. [6; 7]. Досвід формування енергетичної автономії сільських територій через виробництво біопалив вивчала Томашук I.B. [2; 3]. Вивченням сучасних енергетичних та еколого-економічних проблем аграрного сектору України та потенціалу сільського господарства у підвищенні енергозабезпечення країни займаються вчені Калетнік Г.М., Ємчик Т.В. [9], Старосуд В.I., Мулик Т.О. [5], Березюк С.В. [1] та інші.

Формулювання цілей статті. Метою дослідження $є$ розробка на базі Ялтушківської дослідно-селекційної станції Інституту біоенергетичних культур i цукрових буряків НААН України наукових рекомендацій із забезпечення гарантованого щорічного отримання необхідної кількості (на прикладі енергетичної верби) та якості біосировини, придатної для виробництва твердих біопалив та оцінка можливостей iї використання для підвищення енергоефективності сільських територій.

Виклад основних результатів дослідження. Україна традиційно використовує для власних потреб різноманітні джерела енергії, такі як: нафта, природний газ, вугілля, атомна і гідроенергія та інші.

Серед основних споживачів паливно-енергетичних ресурсів домінуюче місце займає аграрний сектор. Споживання енергоресурсів сільським господарством України становило близько 2,87 млн т у.п. у 2020 р., водночас потенціал біомаси галузі у відновлювальній енергетиці оцінюється в понад 10,4 млн т у.п. [13]. Зважаючи на це, Калетнік Г.М. у своїх наукових працях [6;7] обгрунтував значимість агропромислового комплексу України у вирішенні проблем енергетичної та екологічної безпеки держави. Вченим найбільш комплексно розглянуто поняття забезпечення енергетичної незалежності через використання сільськогосподарських відходів як сировини для виробництва біопалив. Академік наголошує, що в Україні $є$ достатня кількість родючих земель, які можуть забезпечити потреби у продуктах харчування населення та рослинній біомасі, яку можна переробити у біопалива та використати для одержання теплової енергії на опалювання приміщень, сушіння сільськогосподарської продукції й інші цілі [6, с. 170].

Поступове зростання попиту на тверді біопалива в Україні сприяє виникненню дефіциту якісної сировини, який можна подолати через закладання енергетичних плантацій рослин короткої ротації. Ці рослини представлені 


\section{EФM}

http://efm.vsau.org/

різноманітними видами енергетичних швидкоростучих сортів деревини, серед яких найпоширенішими у Європі $є$ верба (Salix) та тополя (Populus). Такий новітній напрям енергозабезпечення має ряд суттєвих переваг:

1) закладання плантацій енергетичної верби веде до скорочення забруднення навколишнього середовища, оскільки верби набагато ефективніше засвоюють кадмій та інші важкі метали з грунту, ніж більшість інших культур;

2) такі насадження урізноманітнюють сільський ландшафт і сприяють позитивному балансу $\mathrm{CO}_{2}$;

3) за необхідності, землю під плантаціями енергетичної верби можливо повернути для сільськогосподарського виробництва.

Окрім зазначених переваг, як наголошує Томашук I.В., використання наявного біоенергетичного потенціалу твердопаливної біомаси в Україні забезпечить:

- використання місцевих ресурсів регіону, зокрема і трудових;

- залучення сучасних передових технічних рішень у сферу теплозабезпечення, оновлення технологічних парків існуючого обладнання, розвиток виробництва нового обладнання та діяльності 3 його монтажу та обслуговування, чому сприятиме впровадження об'єктів генерації на біопаливі;

- покращення рівня життя населення в результаті здешевлення енергії, створення нових робочих місць [3, с. 59].

Використання малородючих земель із пересіченим рельєфом дозволить культивувати енергетичні рослини на землях, виведених із сівозміни, яких в Україні налічується близько 5 млн га, а щорічний приріст еродованих земель сягає 80-90 тис. га [1, с. 36]. Вирощування на них біоенергетичних культур, особливо багаторічних, сприятиме збереженню грунту від водної ерозії, зменшенню втрат поживних речовин із поверхневим змивом і деградації грунтів. На цій проблемі акцентує увагу і Калетнік Г.М., наголошуючи, що «призупинення деградаційних процесів у грунтах України та підвищення їхньої ефективної родючості - найважливіше питання сучасності» [8, с. 43].

Поставлені вище завдання $\epsilon$ викликом для авангарду наукових організацій України. Серед таких організацій варто відзначити Ялтушківську дослідно-селекційну станцію Інституту біоенергетичних культур і цукрових буряків НААН України, яка входить до складу Навчально-наукововиробничого комплексу «Всеукраїнський науково-навчальний консорціум» $[5$, c. 23$]$.

У межах наукової діяльності цієї установи було проведено досліди 3 технології вирощування енергетичної верби для виробництва твердих біопалив. 3 метою вивчення та вдосконалення технологічних процесів вирощування енергетичної верби у с. Черешневе були розміщені дослідні посадки у трирічний період 2017-2019 pр. Проаналізувавши дані агрохімічного стану дослідних полів, відмітимо, що, за рівнем родючості, землі $\epsilon$ малопродуктивними, а їх показники якості відстають від середніх у Вінницькій області.

Досліди з технології вирощування енергетичної верби було закладено 
після попередника озимої пшениці, а перед попередником був зайнятий пар кормовими культурами. 3 осені були внесені мінеральні добрива у нормі $\mathrm{N}_{40} \mathrm{P}_{40} \mathrm{~K}_{40}$ кг д.р./га. У результаті дослідів визначено вплив термінів садіння, густоти насаджень та площі живлення на ріст і розвиток рослин енергетичної верби в різні роки вегетації. Площа посадкової ділянки

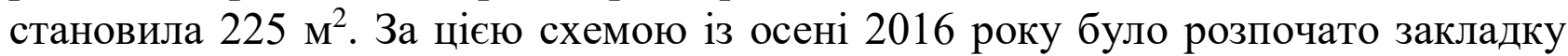
вищеописаного досліду. Інші варіанти були закладені навесні 2017 року і протягом вегетаційного періоду проведені необхідні облік та спостереження (табл. 1).

Таблиця 1

\section{Розгорнута схема досліду з технології вирощування енергетичної верби} живцями Ялтушківською ДСС ІБК і ЦБ НААН України

\begin{tabular}{|c|c|c|c|}
\hline $\begin{array}{c}\text { Варіанти } \\
\text { досліду }\end{array}$ & Пора року садіння & Час садіння & Схема садіння живців \\
\hline 1 & \multirow{6}{*}{ Осінь 2016 р. } & \multirow{3}{*}{ III декада вересня } & 2x70x210 (15 тис. шт./га) \\
\hline 2 & & & 2x100x210 (13 тис. шт./га) \\
\hline 3 & & & 2x150x210 (12 тис. шт./га) \\
\hline 4 & & \multirow{3}{*}{ III декада жовтня } & 2х70x210 (15 тис. шт./га) \\
\hline 5 & & & 2x100x210 (13 тис. шт./га) \\
\hline 6 & & & 2x150x210 (12 тис. шт./га) \\
\hline 7 & \multirow{6}{*}{ Весна 2017 p. } & \multirow{3}{*}{ II декада квітня } & 2x70x210 (15 тис. шт./га) \\
\hline 8 & & & 2x100x210 (13 тис. шт./га) \\
\hline 9 & & & 2x150x210 (12 тис. шт./га) \\
\hline 10 & & \multirow{3}{*}{ I декада травня } & 2x70x210 (15 тис. шт./га) \\
\hline 11 & & & 2×100x210 (13 тис. шт./га) \\
\hline 12 & & & 2x150x210 (12 тис. шт./га) \\
\hline
\end{tabular}

Джерело: узагальнено авторами за результатами проведених досліджень

Аналіз показників росту та розвитку рослин енергетичної верби у 2017 році свідчить, що час посадки та схеми живлення рослин суттєво впливають на кількість живців, які прижилися. Відповідно і врожай біомаси (табл. 2) у перший рік вегетації енергетичної верби становив: при посадці восени, в середньому по всіх варіантах - 25,1 т/га, а під час посадки весною 17,6 т/га. Найбільшим цей показник був за густоти насаджень 15 тис./га.

Таблиия 2

Продуктивність енергетичної верби у дослідженнях, проведених на базі Ялтушківської ДСС ІБК і ЦБ НААН України

\begin{tabular}{|c|c|c|c|}
\hline \multirow{2}{*}{ Показник } & \multicolumn{3}{|c|}{$\begin{array}{c}\text { Схема садіння живців } \\
2 \times 70 \times 210 \text { (15 тис. шт./га) }\end{array}$} \\
\hline & $\begin{array}{c}\text { Другий рік } \\
\text { вегетації }\end{array}$ & $\begin{array}{c}\text { Третій рік } \\
\text { вегетації }\end{array}$ & $\begin{array}{c}\text { Четвертий рік } \\
\text { вегетації }\end{array}$ \\
\hline Урожай сирої маси, т/га & 22,8 & 30,2 & 46,0 \\
\hline Вихід сухої біомаси, т/га & 15,5 & 20,0 & 25,8 \\
\hline Вихід твердих біопалив, т/га & 17,0 & 22,0 & 28,4 \\
\hline Теплоємність твердих біопалив, МДж/га & 16,0 & 16,0 & 16,0 \\
\hline Вихід енергії, ГДж/га & 272,8 & 352,0 & 454,1 \\
\hline
\end{tabular}

Джерело: узагальнено авторами за результатами проведених досліджень

На базі Ялтушківської дослідно-селекційної станції ІБК і ЦБ НААН України була розроблена Програма розведення та селекції чагарникових верб. На основі неї проведені дослідження з різних аспектів виробничого циклу та 
впливу екологічних факторів. Дані польових досліджень, проведених на базі станції, є надзвичайно важливими, оскільки дають можливість об'єктивно оцінити перспективи практичного використання плантацій енергетичної верби. Вважаємо за необхідне провести економічні розрахунки ефективності формування такої плантації. За методологічну основу було обрано програму EcoWillow 2.0. Це найповніший і найсучасніший інструмент фінансового аналізу посівів насаджень верби, створений вченими американського коледжу екологічних наук та лісового господарства «SUNY» [11].

Програмне забезпечення EcoWillow 2.0 на початковому етапі вимагає обгрунтування вихідних даних (табл. 3), де необхідно вказати основні параметри плантацій, такі як: площа та тривалість проєкту, середній приріст біомаси, тривалість ротації, витрати на землю та ціна на біомасу. Економічні розрахунки за плантацією починаються з обгрунтування витрат на посадку. Усі вихідні дані, введені у програму, базувались на даних Ялтушківської дослідно-селекційної станції. Економічна модель розроблена на площу посіву 10 га та термін 20 років. Кінцевим продуктом є вербова тріска 3 прийнятою вологістю 45\%. Середня відстань транспортування обладнання до плантації та кінцевого продукту до замовника була встановлена на рівні 50 км. Діяльність, що входить до моделі - це посадка, збирання врожаю та транспортування.

Таблиия 3

\begin{tabular}{|c|c|c|c|}
\hline & & & \\
\hline & & Іьні дані & \\
\hline Загальна площа поля, га & 10,0 & Орендна плата за землю, грн/га & 850 \\
\hline Площа посадки верби, га & 9,0 & Ціна реалізації біомаси, грн/т & 1100 \\
\hline Площа для обслуговування, га & 1,0 & Інтервал збору врожаю, років & 3,0 \\
\hline Відстань транспортування, км & 50,0 & Середньорічний приріст біомаси, т/га & 22,5 \\
\hline & & і інвестиції & \\
\hline $\begin{array}{l}\text { Витрати на урожай з одиниці площі, } \\
\text { тис. грн/га }\end{array}$ & 7,8 & $\begin{array}{l}\text { Загальні витрати на підготовку грунту до } \\
\text { садіння (видалення бур'янів, гербіцидний } \\
\text { захист, оранка, дискування та ін.), тис. грн/га }\end{array}$ & 10,5 \\
\hline $\begin{array}{l}\text { Витрати на збір врожаю на одиницю } \\
\text { врожаю, грн/т }\end{array}$ & 116 & $\begin{array}{l}\text { Загальні витрати на посадку плантації } \\
\text { енергетичної верби, тис. грн/га }\end{array}$ & 21,2 \\
\hline
\end{tabular}

Джерело: сформовано авторами на базі програми EcoWillow 2.0 [11]

Витрати з посадки верби були поділені на окремі складові: загальні витрати, вартість робочої сили, витрати на відрядження та витрати на обладнання. При посадці було задіяно три робітничі бригади. Загальна площа посадки становить 9 га, оскільки 1 га залишили для необхідності виконання технічних операцій (розворот техніки, складування матеріалів та обладнання й ін.). Погодинна ставка оцінюється відповідно до середньої заробітної плати цієї галузі у регіоні, а погодинна ставка майстра обчислюється відповідно до середньої заробітної плати у сільському та лісовому господарстві. До витрат на обладнання було включено оренду сівалки та витрати пального.

Розрахунки моделі проєкту показують чисту теперішню вартість (NPV), середні витрати, виручку та чистий прибуток у розрахунку на 1 гектар (табл. 4). 
Розрахунки проводяться за заданими умовами, а також за оптимістичним та песимістичним сценарієм NPV, який може коливатися внаслідок зміни витрат або доходів. Оптимістичний сценарій передбачає збільшення доходів на $10 \%$ та зменшення витрат на $10 \%$, а песимістичний, навпаки, - зменшення доходів на $10 \%$ та збільшення витрат на $10 \%$.

Таблиия 4

Результати фінансового аналізу проєкту з вирощування енергетичної верби на базі Ялтушківської ДСС ІБК і ЦБ НААН України

\begin{tabular}{|l|c|}
\hline \multicolumn{1}{|c|}{ Показники } & Значення \\
\hline NPV (Чиста теперішня вартість проєкту), тис. грн & 1224,44 \\
\hline NPV за оптимістичного прогнозу, тис. грн & 1606,69 \\
\hline NPV за песимістичного прогнозу, тис. грн & 842,18 \\
\hline Bнутрішня норма прибутку, \% & 36,9 \\
\hline Внутрішня норма прибутку за оптимістичного прогнозу, \% & 46,1 \\
\hline Внутрішня норма прибутку за песимістичного прогнозу, \% & 28,1 \\
\hline Загальні річні виробничі витрати, грн/га & 11396 \\
\hline Річний валовий дохід, грн/га & 23380 \\
\hline Річний чистий прибуток, грн/га & 11984 \\
\hline Беззбиткова мінімальна ціна біомаси, грн/т & 552,7 \\
\hline Загальна сума інвестицій на запуск проєкту, тис. грн & 237,95 \\
\hline Період окупності інвестицій, років & 5,2 \\
\hline
\end{tabular}

Джерело: сформовано авторами на базі програми EcoWillow 2.0 [11]

Розрахунки показують, що перший товарний урожай із площі 9 га забезпечить виручку 210,42 тис. грн. Чиста теперішня вартість проєкту (NPV) за 20 років його реалізації становитиме 1224,44 тис. грн. Відповідно до оптимістичного сценарію NPV може скласти 1606,69 тис. грн, за песимістичного сценарію - 842,18 тис. грн. Окупність за стандартним сценарієм досягається на 5-му році, після збору другого врожаю. Згідно 3 оптимістичним сценарієм прогнозується зменшення періоду окупності витрат, який буде досягнуто після першого збору врожаю (3 роки), а в песимістичному - окупність прогнозується на 9-му році. Для досягнення більш високих урожаїв важливо вдосконалити селекцію, управління та технології у посадці та збиранні плантацій. Ціна біомаси також має великий вплив на час окупності проєкту. Так, у програму було задано середню вартість тріски 1100 грн/т. Проте, наприклад, якщо ціна зросте до 1200 грн/т, то період скоротиться і окупність буде досягнута на четвертому році.

Витрати на паливо також відіграють значну роль у собівартості, оскільки їх здорожчання спричиняє зростання вартості збирання, транспортування, оранки та інших складових собівартості. Так, збільшення ціни на паливо на $10 \%$ збільшить витрати на посадку на 3\%, витрати на збір врожаю зростуть на $7 \%$, а транспортні витрати - на 6\%. Річний грошовий потік від реалізації біомаси енергетичної верби за різними сценаріями можна розглянути на рис. 1 .

Протягом існування плантації верби основна частина витрат розподілена між статтями на створення, збирання та транспортування відповідно $33 \%, 26 \%$ та 29\%. Інші витрати, такі як вартість землі та страхування, адміністративні витрати та внесення добрив разом складають 12\% від усіх виробничих витрат. 


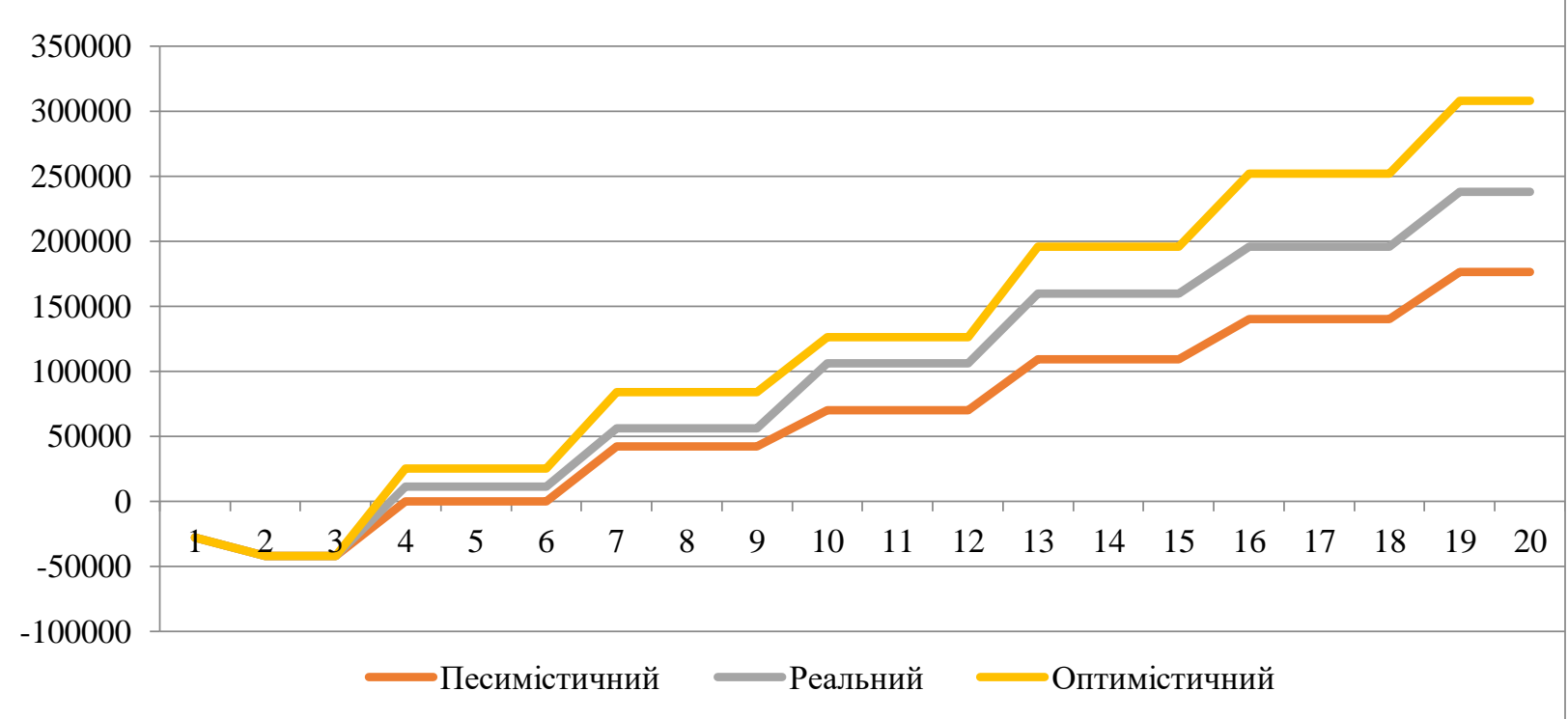

\section{Рuc. 1. Річний грошовий потік від реалізації біомаси енергетичної верби в} умовах просктного середовища Ялтушківської ДСС ІБК і ЦБ НААН України за різними сценаріями, грн/га

Джерело: сформовано авторами на базі програми EcoWillow 2.0 [11]

Середньорічний потенціал біосировини досліджуваного господарства на заявленій площі у 9 га становить 202,5 т/рік. Собівартість тепла, отриманого від згорання енергетичних рослин, більш ніж на 30\% нижча, порівняно 3 теплом, отриманим від згорання вугілля, та майже в 2,5 рази нижча, порівняно 3 природним газом. Теплотворна здатність більшості видів біопалив нижча за теплотворну здатність природного газу, дизельного палива чи мазуту. Це зумовлює той факт, що для отримання однієї і тієї ж кількості тепла потрібно більший об'єм біопалив, ніж традиційного палива. Проте, ціни за одиницю біопалив значно менші, а середній ККД котлів - вищий, ніж у котлів на вугіллі та рідкому паливі (табл. 5).

Таблиия 5

Характеристика теплоти згоряння різних видів палива

\begin{tabular}{|c|c|c|c|c|}
\hline Показник & $\begin{array}{l}\text { Природний } \\
\text { газ }\end{array}$ & $\begin{array}{l}\text { Вугілля (антрацит } \\
\text { АКО 25-100 мм) }\end{array}$ & $\begin{array}{c}\text { Гранули } 3 \\
\text { верби }\end{array}$ & $\begin{array}{l}\text { Вербова } \\
\text { тріска }\end{array}$ \\
\hline Теплотворна здатність, Гкал/тонн $\left(1000 \mathrm{~m}^{3}\right)$ & 8,0 & 7,0 & 4,5 & 2,8 \\
\hline $\begin{array}{l}\text { Витрати палива на виробництво } 1 \text { Гкал тепла, } \\
\text { кг }\left(\mathrm{M}^{3}\right)\end{array}$ & 130,0 & 145,0 & 220,0 & 360,0 \\
\hline Теплотворна здатність, МДж/тонн $(1000$ м³) & 33494,4 & 20934,0 & 18840,6 & 11723,0 \\
\hline $\begin{array}{l}\text { Витрати палива на виробництво } 1 \text { МДж тепла, } \\
\text { кг }\left(\mathrm{M}^{3}\right)\end{array}$ & 3,0 & 4,0 & 5,0 & 9,0 \\
\hline Середнє значення ККД котлів, \% & 92,0 & 60,0 & 87,0 & 70,0 \\
\hline $\begin{array}{l}\text { Витрати палива на виробництво } 1 \text { Гкал тепла } 3 \\
\text { урахуванням ККД котла, кг }\left(\text { м }^{3}\right)\end{array}$ & 140,0 & 241,0 & 252,0 & 514,0 \\
\hline $\begin{array}{l}\text { Витрати палива на виробництво } 1 \text { МДж тепла, } \\
\text { кг }\left(\mathrm{M}^{3}\right)\end{array}$ & 3,3 & 6,6 & 6,0 & 13,0 \\
\hline Ціна одиниці палива, грн/кг (м³) & 6,99 & 5,60 & 2,90 & 1,10 \\
\hline Вартість 1 Гкал тепла, грн & 978,6 & 1350,0 & 730,8 & 565,4 \\
\hline
\end{tabular}

Джерело: розраховано авторами із використанням [14, 16, 17]

Iз даних таблиці 5 помітно, що теплотворна здатність $1 \mathrm{~m}^{3}$ газу

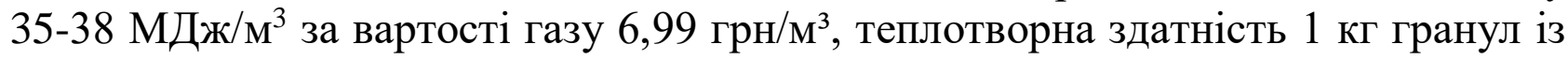


верби - 15,4-18 МДж/кг за вартості гранул 2,9 грн/кг. Вербова тріска виділяє 11-12 МДж/кг, 3 кг гранул вартістю 3,3 грн мають таку ж теплотворну здатність, як 1 м $^{3}$ газу. Це свідчить про те, що вартість біомаси, як палива, у перерахунку на одиницю енергії (Гкал), менша вартості природного газу як мінімум у два рази. Найдешевшою $є 1$ Гкал тепла з вербової тріски - 565,4 грн, а найдорожчим $є$ опалення вугіллям - 1350 грн/1 Гкал.

Провівши розрахунок ефективності опалення офісного приміщення Ялтушківської ДСС площею $150 \mathrm{~m}^{2}$, зазначимо, що керуючись «Методикою розрахунку норм витрат теплової енергії на обігрів будівель» [10] визначено потребу у тепловій енергії на опалювальний сезон в обсязі 26 Гкал. Відповідно до розрахованих даних, вартість опалення за сезон буде становити: вербовою тріскою - 14,7 тис. грн, гранулами з біомаси верби - 19,0 тис. грн, природним газом - 25,44 тис. грн та вугіллям - 35,1 тис. грн. За основу було взято параметри твердопаливного котла вітчизняного виробництва 3 автоматичною подачею палива «ЛІДЕР AUTO» потужністю 50 кВт. Потреба в біопаливі за номінальної продуктивності котла становить 7,2 кг за годину. Час безперервної роботи становить у середньому 10 годин на добу. Відповідно, для опалювання біомасою приміщення площею $150 \mathrm{M}^{2}$, потрібно близько 13 т вербової тріски на один рік, що рівнозначно середньому урожаєві енергетичної верби з посадкової площі 0,6 га.

Забезпечення сільського населення країни тепловою енергією є однією 3 важливих складових діяльності як центральної, так і місцевої влади, одним із головних завдань забезпечення гідної якості життя людини та соціальноекономічної стабільності суспільства.

Для вирішення проблеми забезпечення виробництва твердих біопалив варто застосувати важелі державного регулювання соціально-економічного розвитку, до яких, за твердженням вітчизняних учених Калетніка Г.М. та Ємчик Т.В. [9, с. 19], належать:

- удосконалення державного регулювання доходів у сільській місцевості, зокрема, заробітної плати працівників сільського господарства, підвищення іiі рівня до середнього в країні;

- розробка та реалізація державних програм розвитку соціальної інфраструктури сільських територій, благоустрою сільських поселень;

- формування місцевими державними адміністраціями комплексних програм енергопостачання та енергозбереження у сільській місцевості;

- застосування програмно-цільового підходу як інструмента державного регулювання розвитку сільських територій.

Одним із найбільш дієвих шляхів забезпечення енергоефективності сільських територій пропонуємо розглядати створення енергетичних кооперативів. На основі світового досвіду нами виокремлено чотири економічних моделі енергетичних кооперативів, які можуть застосовувати українські сільські громади:

1. Виробництво палива з відходів сільського, лісового господарства та енергетичних швидкорослих видів деревини. 
2. Альтернативна електростанція, яка продає електричну енергію у мережу за «зеленим тарифом».

3. Виробництво та використання біогазу з біомаси.

4. Виготовлення та використання сонячних водонагрівачів [4, с. 35].

У межах проведених досліджень вирішення поставлених завдань пропонуємо розглядати у розробці моделі енергетичного забезпечення територіальних громад на основі створення енергетичного кооперативу 3 вирощування енергетичних сортів верби та виробництва палива з іiї біомаси, а також відходів сільського та лісового господарства. Потенційними споживачами продуктів діяльності кооперативу будуть комунальні заклади та місцеве населення.

Сільські територіальні громади мають хороші можливості для забезпечення місцевих енергетичних потреб. У 2018 році об'єднані громади отримали майже 1,5 мільйона гектарів сільськогосподарських угідь за межами населених пунктів, що перебувають у комунальній власності $[9$, с. 18].

Перешкодою на шляху реалізації кооперативних енергетичних проєктів * можуть стати певні бар'єри: низький рівень обізнаності та розуміння агротехнічних прийомів вирощування енергетичної верби, а також принципів управління виробничим процесом; відсутність розуміння особливостей та переваг використання біомаси в енергетичних цілях у місцевих жителів, політиків та громадськості; відсутність функціонуючого та організованого ланцюжка постачання складових виробничого процесу, які б відповідали потребам зацікавлених сторін системи біоенергетики. Усунення цих проблем можливе через організацію міжсекторної науково-виробничої інтеграції на місцевому рівні. Прикладом ефективності такої організації можна розглядати створений у США Північно-східний Консорціум деревної біомаси (NEWBio) регіональної мережі університетів, підприємств та урядових організацій, яка займається створенням надійних та стійких ланцюжків створення та передачі енергії з біомаси [15]. Він надає виробникам та іншим зацікавленим сторонам освітньо-пропагандистські послуги та послуги з технічної підтримки.

Модель описаної установи в Україні доцільно було б спроєктувати на базі ННВК «Всеукраїнський науково-навчальний консорціум», який має розгалужену структуру, до складу якої входять Вінницький національний аграрний університет у складі власне університету, 5 коледжів, Науководослідного господарства «Агрономічне» ВНАУ; Інститут біоенергетичних культур і цукрових буряків Національної академії аграрних наук України в складі інституту, 5 дослідно-селекційних станцій, 2 дослідних господарств та Інститут продовольчих ресурсів НААНУ зі структурними підрозділами. Консорціум може взяти на себе обов'язки співпраці з науковцями, виробниками та кінцевими споживачами, щоб забезпечити координацію комунікації між університетом, громадськістю, владою та бізнесом із метою розширення сировинної бази, вдосконалення технології вирощування енергетичної верби та налагодження ланцюга поставок екологічно чистої енергії споживачам.

Висновки. За результатами проведених досліджень варто відзначити, що серед основних споживачів паливно-енергетичних ресурсів домінуюче місце 
займає аграрний сектор, який одночасно $є$ і сировинною базою виробництва біомаси, що вважаємо перспективою для розвитку в Україні галузі біоенергетики. Серед різновидів біопалив для генерації теплової енергії найбільш перспективним варто розглядати тверді їх види. Зростання виробництва твердих біопалив в Україні породжує проблему зі стабільного постачання якісної сировини для його виробництва. Цю проблему пропонується вирішити завдяки вирощуванню та використанню енергетичних видів деревини. Ці рослини представлені видами енергетичних швидкоростучих сортів деревини, серед яких найпоширенішою у Європі $\epsilon$ верба (Salix).

Серед передових наукових організацій України, які здатні забезпечити створення високопродуктивних сортів i гібридів енергетичних рослин, розглянуто Ялтушківську дослідно-селекційну станцію Інституту біоенергетичних культур і цукрових буряків НААН України, яка входить до складу Навчально-науково-виробничого комплексу «Всеукраїнський науковонавчальний консорціум» та плідно займається селекційною роботою енергетичної верби. У межах наукової діяльності станції було проведено досліди з технології вирощування енергетичної верби для виробництва твердих біопалив. У результаті проведених досліджень визначено, що собівартість тепла, отриманого від згорання гранул із енергетичних рослин, більш ніж на $40 \%$ нижча, порівняно з теплом, отриманим від згорання природного газу, та майже в 2,5 рази нижча, порівняно з вугіллям.

За результатами економічних розрахунків варто відзначити, що на рентабельність посівів біомаси верби впливають багато змінних, а саме: вихід біомаси, ціна на неї, вартість посадкового матеріалу, ефективність збиральних робіт, транспортні відстані, використання та вартість добрив.

Нові перспективи розвитку біоенергетичного сектора в Україні можна очікувати завдяки впровадженню цільового вирощування високопродуктивних рослин, використанню новітніх технологій і технічних засобів виробництва та різних видів біопалив. Практична реалізація таких проєктів можлива на основі створення у сільській місцевості енергетичних кооперативів. Реалізація таких місцевих енергетичних проєктів забезпечуватиме енергонезалежність громад, створення робочих місць та економічне зростання. Зазначені ініціативи можуть налагодити перехід до низьковуглецевої енергетичної системи, допомогти побудувати зацікавленість та довіру споживачів до біопалив, а також забезпечити зростання їх частки на ринку енергоносіїв.

\section{Список використаних джерел}

1. Березюк С.В., Зубар I.В. Сучасні економіко-екологічні аспекти застосування добрив у рослинництві. Економіка АПК. 2019. № 10. С. 34-43. DOI: https://doi.org/10.32317/2221-1055.201910034.

2. Гончарук I.B., Томашук I.В. Економічна ефективність енергетичної автономії АПК за рахунок використання біопалив. Економіка, фінанси, менеджмент: актуальні питання науки і практики. 2019. № 2 (42). С. 7-19. DOI: 10.37128/2411-4413-2019-2-1. 
3. Гончарук I.B., Томашук I.В. Вплив еколого-економічного фактору на особливості організаційно-економічного механізму використання ресурсного потенціалу сільських територій. Економіка, фінанси, менеджмент: актуальні питання науки і практики. 2017. № 4 (20). С. 52-62.

4. Гончарук I.В. Досвід формування енергетичної автономії сільських територій: оцінка ролі кооперативів. Економіка, фінанси, менеджмент: актуальні питання науки $i$ практики. 2020. № 1 (51). С. 23-40. DOI: $10.37128 / 2411-4413-2020-1-2$.

5. Гончарук I.B., Старосуд B.I., Мулик Т.О. Фінансові результати сільськогосподарських підприємств: механізм формування та аналітична оцінка (на прикладі Ялтушківської дослідно-селекційної станції ІБК і ЦБ НААН України). Економіка, фінанси, менеджмент: актуальні питання науки $i$ практики. 2018. № 3 (31). С. 18-34.

6. Калетнік Г.М. Диверсифікація розвитку виробництва біопалив - основа забезпечення продовольчої, енергетичної, економічної та екологічної безпеки України. Вісник аграрної науки. 2018. № 11 (96). С. 169-176. DOI: https://doi.org/10.31073/agrovisnyk201811-21.

7. Калетнік Г.М. Роль агропромислового комплексу України у вирішенні проблем енергетичної та екологічної безпеки держави. Агросвіт. 2009. № 22. С. 2-5.

8. Калетнік Г.М., Гончарук Т.В. Перспективи використання стічних каналізаційних вод м. Вінниці для підживлення польових культур: вітчизняний та зарубіжний досвід. Збалансоване природокористування. 2016. № 3. С. $42-47$.

9. Калетнік Г.М., Смчик Т.В. Ефективність функціонування національного господарства та організаційні форми управління національною економікою. Економіка, фінанси, менеджмент: актуальні питання науки і практики. 2020. № 2 (52). C. 7-22. DOI: 10.37128/2411-4413-2020-2-1.

10. Методика розрахунку норм витрат теплової енергії на обігрів будівель. URL: https://zakon.rada.gov.ua/rada/show/n0001466-04\#Text (дата звернення: 18.05.2021).

11. Офіційний веб-сайт The Willow Project at SUNY-ESF. URL: https://www.esf.edu/willow/download.htm (дата звернення: 21.05.2021).

12. Офіційний веб-сайт Верховної Ради України. URL: www.static.rada.gov.ua (дата звернення: 18.05.2021).

13. Офіційний веб-сайт Державного агентства 3 енергоефективності та енергозбереження України. Департамент відновлюваних джерел енергії. URL: http://saee.gov.ua (дата звернення: 15.05.2021).

14. Офіційний веб-сайт компанії BAT «Альфа-Инвест». URL: https://ainvest.com.ua (дата звернення: 28.05.2021).

15. Офіційний веб-сайт Північно-східного Консорціуму деревної біомаси. URL: www.newbio.psu.edu/ (дата звернення: 21.05.2021).

16. Офіційний веб-сайт торгівельної інтернет-платформи «Пром». URL: https://prom.ua (дата звернення: 28.05.2021).

17. Практичний посібник 3 використання біомаси в якості палива у муніципальному секторі України. URL: http://bioenergy.in.ua/ (дата звернення: 15.05.2021). 


\section{References}

1. Berezjuk, S.V., \& Zubar, I.V. (2019). Suchasni ekonomiko-ekolohichni aspekty zastosuvannia dobryv u roslynnytstvi [Modern economic and ecological aspects of fertilizer application in the crop production]. Ekonomika APK - The Economy of Agro-Industrial Complex, 10, 34-43. DOI: https://doi.org/10.32317/2221-1055.201910034 [in Ukrainian].

2. Honcharuk, I.V., \& Tomashuk, I.V. (2019). Ekonomichna efektyvnist enerhetychnoi avtonomii APK za rakhunok vykorystannia biopalyv [Economic efficiency of energy autonomy of agroindustrial complex due to the use of biofuels]. Ekonomika, finansy, menedzhment: aktualni pytannya nauky i praktyky - Economy, finances, management: topical issues of science and practical activity, 2 (42), 7-19. DOI: 10.37128/2411-4413-2019-2-1 [in Ukrainian].

3. Honcharuk, I.V., \& Tomashuk, I.V. (2017). Vplyv ekoloho-ekonomichnoho faktoru na osoblyvosti orhanizatsiino-ekonomichnoho mekhanizmu vykorystannia resursnoho potentsialu silskykh terytorii [Influence of ecological and economic factor on features of organization of organizational and economic mechanism of use of resource potential of rural territories]. Ekonomika, finansy, menedzhment: aktualni pytannia nauky $i$ praktyky - Economy, finances, management: topical issues of science and practical activity, 4 (20), 52-62 [in Ukrainian].

4. Honcharuk, I.V. (2020). Dosvid formuvannia enerhetychnoi avtonomii silskykh terytorii: otsinka roli kooperatyviv [Experience of formation of energy autonomy of rural territories: assessment of the role of cooperatives]. Ekonomika, finansy, menedzhment: aktualni pytannia nauky i praktyky - Economy, finances, management: topical issues of science and practical activity, 1 (51), 23-40. DOI: 10.37128/2411-4413-2020-1-2 [in Ukrainian].

5. Honcharuk, I.V., Starosud, V.I., \& Mulyk, T.O. (2018). Finansovi rezuljtaty siljsjkoghospodarsjkykh pidpryjemstv: mekhanizm formuvannja ta analitychna ocinka (na prykladi Jaltushkivsjkoji doslidno-selekcijnoji stanciji IBK i CB NAAN Ukrajiny) [Financial results of agricultural enterprises: the mechanism of formation and analytical assessment (on the example of Yaltushkiv experimental breeding station of the Institute of bioenergy crops and sugar beets of the National Academy of Agrarian Sciences of Ukraine)]. Ekonomika, finansy, menedzhment: aktualni pytannia nauky $i$ praktyky - Economy, finances, management: topical issues of science and practical activity, 3 (31), 18-34. DOI: https://doi.org/10.31073/agrovisnyk201811-21 [in Ukrainian].

6. Kaletnik, G.M. (2018). Dyversyfikacija rozvytku vyrobnyctva biopalyv - osnova zabezpechennja prodovoljchoji, energhetychnoji, ekonomichnoji ta ekologhichnoji bezpeky Ukrajiny [Diversification of biofuel production development - the basis for ensuring food, energy, economic and environmental security of Ukraine]. Visnyk aghrarnoji nauky - Agrarian Science Journal, 11 (96), 169-176. DOI: https://doi.org/10.31073/agrovisnyk201811-21 [in Ukrainian].

7. Kaletnik, G.M. (2009). Rolj aghropromyslovogho kompleksu Ukrajiny u vyrishenni problem energhetychnoji ta ekologhichnoji bezpeky derzhavy [The role of the agro-industrial complex of Ukraine in solving the problems of energy and environmental security of the state]. Aghrosvit-Aghrosvit, 22, 2-5 [in Ukrainian]. 
8. Kaletnik, G.M., \& Honcharuk, T.V. (2016). Perspektyvy vykorystannia stichnykh kanalizatsiinykh vod $\mathrm{m}$. Vinnytsi dlia pidzhyvlennia poliovykh kultur: vitchyznianyi ta zarubizhnyi dosvid [Prospects of using of sewage waters in Vinnytsia for reaping of field crops: domestic and foreign experience]. Zbalansovane pryrodokorystuvannia - Balanced Environmental Management, 3, 42-47 [in Ukrainian].

9. Kaletnik, G.M., \& Yemchyk, T.V. (2020). Efektyvnistj funkcionuvannja nacionaljnogho ghospodarstva ta orghanizacijni formy upravlinnja nacionaljnoju ekonomikoju [The efficiency of the national economy and organizational forms of management of the national economy]. Ekonomika, finansy, menedzhment: aktualni pytannia nauky $i$ praktyky - Economy, finances, management: topical issues of science and practical activity, 2 (52), 7-22. DOI: 10.37128/2411-4413-2020-2-1 [in Ukrainian].

10. Metodyka rozrakhunku norm vytrat teplovoji energhiji na obighriv budivelj [Methods of calculating the norms of thermal energy consumption for heating buildings]. (2004, November 26). zakon.rada.gov.ua. Retrieved from: https://zakon.rada.gov.ua/rada/show/n0001466-04\#Text/ [in Ukrainian].

11. Ofitsiinyi web-sait The Willow Project at SUNY-ESF [The official website of The Willow Project at SUNY-ESF]. esf.edu. Retrieved from: https://www.esf.edu/willow/download.htm [in English].

12. Ofitsiinyi web-sait Verkhovnoji Rady Ukrajiny [Official website of the Verkhovna Rada of Ukraine]. static.rada.gov.ua. Retrieved from: www.static.rada.gov.ua [in Ukrainian].

13. Ofitsiinyi web-sait Derzhavnogho aghentstva $\mathrm{z}$ energhoefektyvnosti ta energhozberezhennja Ukrajiny. Departament vidnovljuvanykh dzherel energhiji [Official website of the State Agency for Energy Efficiency and Energy Saving of Ukraine. Department of Renewable Energy]. saee.gov.ua. Retrieved from: http://saee.gov.ua. [in Ukrainian].

14. Ofitsiinyi web-sait kompaniji VAT «Aljfa-Ynvest» [Official website of the OJSC «Alfa-Invest»]. a-invest.com.ua. Retrieved from: https://a-invest.com.ua [in Ukrainian].

15. Ofitsiinyi web-sait Pivnichno-skhidnogho Konsorciumu derevnoji biomasy. [Official website of the Northeast Woody/Warm-season Biomass Consortium]. newbio.psu.edu. Retrieved from: www.newbio.psu.edu/ [in English].

16. Ofitsiinyi web-sait torghiveljnoji internet-platformy «Prom» [Official website of the Trading Internet-platform «Prom»]. prom.ua. Retrieved from: https://prom.ua [in Ukrainian].

17. Praktychnyj posibnyk $\mathrm{z}$ vykorystannja biomasy $\mathrm{v}$ jakosti palyva $\mathrm{u}$ municypaljnomu sektori Ukrajiny [Practical guide to the use of biomass as a fuel in the municipal sector of Ukraine]. bioenergy.in.ua. Retrieved from: http://bioenergy.in.ua [in Ukrainian].

\section{Відомості про автора}

ГОНЧАРУК Інна Вікторівна - доктор економічних наук, професор кафедри економіки та підприємницької діяльності, проректор 3 науковопедагогічної, наукової та інноваційної діяльності, Вінницький національний 
аграрний університет (21008, м. Вінниця, вул. Сонячна, 3, e-mail: vnaunauka2020@gmail.com).

ЯРЕМЧУК Наталія Валеріївна - кандидат економічних наук, старший викладач кафедри адміністративного менеджменту та альтернативних джерел енергії, Вінницький національний аграрний університет (21008, м. Вінниця, вул. Сонячна, 3, e-mail: Yaremchuk_Nat@i.ua).

HONCHARUK Inna - Doctor of Economic Sciences, Professor of the Department of Economics and Entrepreneurship, Vice-Rector for Scientific and Pedagogical, Scientific and Innovative Activities, Vinnytsia National Agrarian University (21008, Vinnytsia, 3, Soniachna Str., e-mail: vnaunauka2020@gmail.com).

YAREMCHUK Natalia - Candidate of Economic Sciences, Senior Lecture of the Department of Administrative Management and Alternative Energy Sources, Vinnytsia National Agrarian University (21008, Vinnytsia, 3, Soniachna Str., e-mail: Yaremchuk_Nat@i.ua).

ГОНЧАРУК Инна Викторовна - доктор экономических наук, профессор кафедры экономики и предпринимательской деятельности, проректор по научно-педагогической, научной и инновационной деятельности, Винницкий национальный аграрный университет $(21008$, г. Винница, ул. Сонечная, 3, e-mail: vnaunauka2020@gmail.com).

ЯРЕМЧУК Наталья Валерьевна - кандидат экономических наук, старший преподаватель кафедры административного менеджмента и альтернативных источников энергии, Винницкий национальный аграрный университет (21008, г. Винница, ул. Солнечная, 3, e-mail: Yaremchuk_Nat@i.ua).

UDC: 331.103.246

DOI: $10.37128 / 2411-4413-2021-4-2$

OPPORTUNITIES OF TELEWORK AND ITS IMPACT ON THE ECONOMY
JEKABSONE Sandra, Doctor of Economic Sciences, Professor

SKRIBANE Irina, Analyst of the the Ministry of Economics of Latvia, Master of Economics, Lecturer, Faculty of Business, Management and Economics, University of Latvia

SPROGE Ilze,

Doctor of Public Management, Associate Professor of the Department of Corporate Finance and Economics Faculty of Engineering Economics and Management, Riga Technical University (Riga, Latvia)

The transformation of the labour market towards more flexible work conditions took place long before the Covid-19 pandemic. In 2019, in the EU Member States, on average, $14.4 \%$ of the 